\title{
PASSADO E PRESENTE EM PERSPECTIVA: memó- ria e anterioridade nas literaturas americanas
}

Luciano Passos Moraes

(Colégio Pedro 11)

https://orcid.org/0000-0002-7751-7468

\begin{abstract}
BERND, Zilá. A persistência da memória: romances da anterioridade e seus modos de transmissão intergeracional. Porto Alegre: BesouroBox, 2018. 172p.
\end{abstract}

O título da mais famosa obra de Salvador Dalí, de 1931, é tomado de empréstimo por Zilá Bernd em sua recente publicação A persistência da memória (2018), na qual apresenta um minucioso estudo acerca dos temas da memória, da anterioridade e da transmissão intergeracional. A conhecida imagem do pintor surrealista, com relógios derretendo, parece pertinente como ilustração e ponto de partida para as reflexões da autora, pois Bernd se debruça sobre as relações entre passado e escrita de modo a ressignificar a permanência, ao longo dos tempos, de processos de rememoração das genealogias, analisando a questão da filiação em romances contemporâneos nas Américas.

Dividida em três partes, a obra segue um percurso que revisita, primeiramente, teorias ligadas à memória cultural e geracional (Parte I); em seguida, propõe uma análise comparada de romances brasileiros, colocando em prática tais teorias (Parte II); finalmente, amplia os horizontes trazendo a leitura das transferências culturais interamericanas, estabelecendo relações entre universos culturais e literários que trazem ao centro os temas das identidades compósitas e das formações culturais híbridas (Parte III).

Na primeira parte (“Anterioridades/Interioridades"), a autora aborda teorias de Assmann e de Huyssen que indicam que, se a memória humana pode ser vista em termos de herança cultural - aquilo que é trans- 
mitido ao longo de gerações e que permanece no imaginário individual e coletivo como familiaridade, partindo de objetos ou ritos que remetem a lembranças ancestrais e culturais -, ela também deve ser considerada em termos de memória do presente, pela exploração de entre-lugares que ultrapassam um passado em termos historiográficos para presentificar ou reconstituir esse passado em suas implicações políticas e identitárias, como bem o faz Régine Robin.

Para Bernd, os limites entre os chamados romances da anterioridade e os de filiação são fluidos, pois ela considera que ambas as formas de escrita são autoficcionais, embora se distingam sob os vieses da ancestralidade (herança e parentesco) e da fragmentação (traços e vestígios de passado que se fazem presente no romance memorial). Complementa e aprofunda o estudo a questão da transmissão, observada através dos tempos tanto na escrita historiográfica quanto na literária, em termos de continuidade ou de ruptura. Ao trazer exemplos de escritores como Maryse Condé e Patrick Chamoiseau, a autora valoriza a transmissão oral dos conteurs, processo tão presente nas literaturas caribenhas, e que se perpetua por meio da ressignificação de processos diaspóricos e da análise das relações entre o passado traumático e a construção de "culturas transculturadas" em espaços americanos. Soma-se a essa reflexão a ideia de que a transmissão, segundo Pierre Ouellet, está ligada à atualização dos mitos fundadores, papel desempenhado pela literatura contemporânea ao se questionarem identidades e tradições, preservando-as e, ao mesmo tempo, revitalizando-as à luz de sua compreensão no presente.

A segunda parte da obra ("Filiações") focaliza a transmissão intergeracional em romances brasileiros, partindo do romance genealógico (narrativas cronologicamente organizadas e de tendência totalizadora) para verificar formas contemporâneas do romance memorial ou de família, que estão relacionados à apreensão da história coletiva por meio de percursos individuais. Dentre os exemplos citados destaca-se a retomada do gênero por Luiz Antonio de Assis Brasil, que em muitos de seus romances constrói sagas familiares que atravessam gerações, mas nas quais subverte a linearidade temporal ao propor um "jogo de intersecções entre passado e presente" (p. 43).

Outros modos de expressão da ancestralidade são observados por Bernd nesta parte do estudo, merecendo destaque a análise da transmissão via laços familiares em Conceição Evaristo, Eliane Brum e Adriana Lisboa, entre outros. As leituras atentas das obras revelam o surgimento de 
novas formas de romances de filiação, em que são desvendados períodos de vida familiar na hesitação entre as formas romanesca e autobiográfica. Como resultado, Bernd demonstra que a exploração das lacunas do passado através da rememoração, impulso recorrente nos romances de filiação contemporâneos, permite (ou amplia) o conhecimento de memórias familiares e revela percursos desconhecidos ou ocultados pelo tempo, o que traz implicações substanciais na reconstrução identitária das personagens no presente. A autora observa nas obras, por fim, "o esforço de recuperação da memória como arquivo, mas sobretudo de recriação de espaços de recordação" (p. 102), movimento no qual os descaminhos da memória - como o esquecimento ou os silenciamentos - servem de alimento para a reconstituição da memória cultural ao serem colocados em perspectiva os traumas passados, não somente familiares, mas também geracionais.

$\mathrm{Na}$ terceira parte do estudo ("Americanidades") é reconstituído o percurso desenvolvido pela autora nos últimos anos, cujos projetos de pesquisa culminaram na organização de dois dicionários e de um glossário que contribuíram para "cartografar o imaginário coletivo das Américas" (p. 122). Bernd revisita os bastidores destas publicações para revelar ao leitor seus aspectos norteadores e, principalmente, o universo de valores que nelas se construiu, através de consistentes estudos seja com relação aos mitos e figuras literárias americanas, seja no que diz respeito à análise de processos ligados às mobilidades culturais nas Américas.

Tais empreitadas trouxeram como legado novos caminhos rumo à compreensão do problema do pertencimento e da reconstrução identitária, passando por questões relativas à memória cultural e às fraturas coletivas observadas no curso da história. $\mathrm{O}$ aspecto transcultural ressurge como espinha dorsal de um projeto maior, o de desvelar as reminiscências que alimentam a reescrita dos mitos fundadores, por meio da fragilização da ideia de "grandes narrativas" e da valorização dos relatos calcados na hibridação cultural, importante contribuição para a ruptura do cânone tradicional. O apagamento ou a fragilização dos limites territoriais "na contramão dos discursos sociais dominantes" (p. 131) permitiu a construção de novos olhares em direção aos imaginários americanos, resultado de trabalhos coletivos que fizeram e fazem avançar os estudos de literaturas antes consideradas minoritárias ou relegadas a posições periféricas.

As relações entre as noções de memória e de comunidades culturais são focalizadas ao final da terceira parte. Nele a pesquisadora indica caminhos para a compreensão das literaturas americanas como espaço plu- 
ral, híbrido, nas quais a noção de mobilidade é um dos principais fatores para a ressignificação da diversidade e do contato com o outro.

$\mathrm{O}$ estudo se encerra com (in)conclusões a respeito do tema da filiação, num apanhado de ideias que aprofundam e expandem os horizontes de compreensão das relações plurais estabelecidas entre literatura, história e cultura e das tensões e espaços intervalares do individual e do coletivo. Trata-se de obra fundamental não só por atualizar os estudos em torno da memória, mas sobretudo por trazer à luz os aspectos mais relevantes para a observação, nos dias de hoje, do entrecruzamento entre passado e presente, sem deixar de valorizar literaturas e culturas frequentemente deixadas de lado pela historiografia literária tradicional. A exemplo de outras obras de Zilá Bernd, verifica-se nesta publicação o compromisso com o estabelecimento de novas perspectivas de análise, por meio de extensa e pertinente seleção bibliográfica que contribui em grande medida para o aprofundamento dos estudos literários interamericanos, ratificando a posição de destaque conquistada pela autora ao longo de seu percurso.

Recebido em: 13/08/2018

Aceito em: 18/02/2019 